\title{
PEMBUATAN ZAT PENGATUR TUMBUH (ZPT) ORGANIK CAIR PADA KELOMPOK TANI TELADAN KECAMATAN SUMBERJAMBE, KABUPATEN JEMBER, JAWA TIMUR
}

\section{MANUFACTURE OF LIQUID ORGANIC GROWTH ADMINISTRATIVE IN TANI TELADAN GROUP, SUMBERJAMBE DISTRICT, JEMBER DISTRICT, EAST JAVA}

\author{
Sepdian Luri Asmono ${ }^{\# 1}$, Dhanang Eka Putra ${ }^{* 2}$, Irma Harlianingtyas ${ }^{\# 3}$ \\ ${ }^{\#}$ Jurusan Produksi Pertanian, Politeknik Negeri Jember \\ Jalan Mastrip, Kotak Pos 164 Jember \\ ${ }^{1}$ sepdian@polije.ac.id \\ 3irma.harlia.09@gmail.com \\ *Jurusan Manajemen Agribisnis, Politeknik Negeri Jember \\ Jalan Mastrip, Kotak Pos 164 Jember \\ ${ }^{2}$ dhanangeka@polije.ac.id
}

Abstrak

Beberapa bahan organik diketahui mengandung unsur hara dan zat pengatur tumbuh alami (ZPT), seperti air kelapa, jagung muda, taoge, bonggol pisang, rebung. Bahan-bahan ini juga menjadi substrat untuk perbanyakan mikroorganisme lokal yang baik untuk tanah. Oleh karena itu, tujuan kegiatan pengabdian masyarakat di Kelompok Tani Teladan Sumberjambe Jember adalah untuk mengenalkan, meningkatkan keterampilan dan menerapkan teknologi fermentasi mikroorganisme lokal (bioaktivator) dengan menggunakan bahan organik yang mengandung zat pengatur tumbuh alami. Kegiatan ini menggunakan metode dan praktek langsung pembuatan ZPT alami. Hasil yang dicapai berdasarkan indikator pelaksanaan diklat ini diantaranya adalah respon kehadiran peserta diklat yang diikuti oleh 30 orang atau $100 \%$ diundang untuk mengikuti acara diklat. Selain itu, selama kegiatan ekstraksi dan fermentasi bahan organik terlihat peserta mengetahui urutan tata cara pembuatan ZPT Alam dari hasil diskusi dan tanya jawab. Selain itu, penilaian kuantitatif keberhasilan kegiatan pembekalan dilakukan melalui pre-test dan post-test. Hasil yang diperoleh pada tes awal rata-rata pemahaman tentang ZPT alam adalah 25, sedangkan nilai rata-rata post test setelah pelaksanaan adalah 75 . Berdasarkan hasil pre-test dan post-test, terdapat peningkatan yang signifikan pada pengetahuan peserta tentang pengatur tumbuh organik. Hasil tersebut juga dapat menunjukkan bahwa kegiatan ini mampu menambah pengetahuan peserta. Pada praktiknya sekitar $80 \%$ peserta telah mampu mengekstrak dan mencampurkan bahan untuk proses fermentasi. Indikator keberhasilannya terlihat dari bahan ZPT alami yang terfermentasi baik yang bercirikan warna coklat dan bau asam menyerupai tapai.

Kata kunci: Zat Pengatur Tumbuh Alami, Organik, EM-4, Sumberjambe

Abstract

Some organic ingredients are known to contain nutrients and natural plant growth regulators (PGR), such as coconut water, young corn, sprouts, banana weevil, bamboo shoots. These materials are also a substrate for multiplying local microorganisms that are good for the soil. Therefore, the purpose of community service activities in the Exemplary Farmers Group, Sumberjambe Jember is to introduce, improve skills and implement local microorganism fermentation technologies (bioactivators) using organic materials that contain natural plant growth regulators. This activity uses direct methods and practices for making natural PGR. The results achieved based on the indicators of the implementation of this training include the response of the attendance of the training participants attended by 30 people or $100 \%$ invited to attend the training event. In addition, during the extraction and fermentation activities of organic materials, it was seen that participants knew the sequence of procedures for making Natural PGR from the results of discussions and questions and answers. In addition, a quantitative assessment of the success of the briefing activity was carried out through pre-test and post-test. The results obtained in the initial test mean the understanding of natural PGR is 25, while the post-test mean score after implementation is 75. Based on the pre-test and post-test results, there is a significant increase in participants' knowledge about organic growth regulators. These results can also indicate that this activity is able to increase participants' knowledge. In practice about $80 \%$ of participants have been able to extract and mix ingredients for the fermentation process. The indicator of success is evident from the well-fermented natural PGR material which is characterized by a brown color and acidic odor resembling tapai.

Keywords : Natural Plant Growth Regulator, Organic, EM-4, Sumberjambe 


\section{PENDAHULUAN}

Sejalan dengan kemajuan teknologi, modernisasi pertanian hendaknya tetap menyelaraskan dengan kearifan lokal melalui pemanfaataan sumber daya yang ada secara berimbang, sehingga mengurangi ketergantungan pupuk dan pestisida anorganik. Hal yang terpenting juga adalah menyiapkan sumber daya manusia yang tetap berwawasan lingkungan dan berkelanjutan dalam pengelolaan usahataninya. Desa Sumberjambe, Kecamatan Sumberjambe, Kabupaten Jember, Jawa Timur, secara umum lebih dari $66 \%$ penduduknya bermata pencaharian sebagai petani [1]. Permasalahan yang dihadapi para petani adalah menurunnya produksi dan sering terjadi kelangkaan pupuk. Diketahui juga bahwa petani sangat tergantung pada penggunaan pupuk dan pestisida anorganik, dan secara tidak langsung hal tersebut berdampak pada menurunnya produktifitas tanaman karena menurunnya kualitas tanah.Oleh sebab itu alternatif untuk mengurangi penggunaan dari pupuk kimia adalah meningkatkan kesadaran petani untuk memanfaatkan kembali bahan-bahan organik alami untuk dijadikan pupuk dan zat pengatur tumbuh tumbuhan (ZPT).

Penerapan teknologi dalam kegiatan ini adalah dengan memanfaatkan bahan organik yang ada disekitar kita untuk dapat diolah menjadi nutrisi dan ZPT alami yang dapat dimanfaatkan tanaman kembali. Beberapa bahan organik diketahui mengandung nutrisi dan ZPT alami yang dapat memacu pertumbuhan tanaman, seperti air kelapa [2], jagung muda, kecambah, bonggol pisang, rebung[3]-[5]. Bahan-bahan tersebut juga sekaligus merupakan substrat untuk memperbanyak mikroorganisme lokal yang baik untuk tanah.

Saat ini kelompok mikroorganisme lokal/bioaktifator dapat dengan mudah didapat di pasaran, akan tetapi cara penggunaannya juga butuh keterampilan khusus agar hormon dan mikroorganisme lokal dapat dimanfaatkan dengan baik oleh tanaman. Oleh sebab itu tujuan kegiatan pengabdian masyarakat ini adalah mengenalkan, meningkatkan ketrampilan dan menerapkan teknologi fermentasi mikroorganisme lokal (bioaktifator) menggunakan bahan-bahan organik yang mengandung zat pengatur tumbuh tumbuhan alami. Selain itu, untuk menunjang peningkatan pendapatan petani tersebut, diperlukan juga adanya pelatihan untuk teknik pengemasan dan pemasaran zpt alami yang dihasilkan.

\section{TARGET DAN LUARAN}

Sasaran pengabdian masyarakat ini adalah para petani dari Kelompok Tani Teladan Desa Sumberjambe, Kabupaten Jember. Kegiatan pengabdian kepada masyarakat ini dilakukan atas pertimbangan bahwa pentingnya pengelolaan sumber daya alam yang berwawasan lingkungan dengan mengurangi penggunaan bahan anorganik untuk pertanian. Justru disekitar kita banyak bahan organik yang dapat digunakan sebagai sumber ZPT alami untuk memacu pertumbuhan dan perkembangan tanaman seperti jagung muda, kecambah, air kelapa, bonggol pisang. Luaran yang didapatkan adalah meningkatnya keterampilan petani. Selain itu luaran lainnya adalah adanya naskah yang terpublikasi pada jurnal atau artikel yang terbit pada media masaa elektronik.

\section{METODE PELAKSANAAN}

\section{Persiapan awal}

Persiapan awal meliputi kordinasi dengan tim terkait pembagian tugas. Serta koordinasi dengan ketua kelompok tani dan mempersiapkan sarana dan prasarana yang akan digunakan untuk kegiatan penyuluhan dan kegiatan pembuatan ZPT organik.

\section{Penyuluhan}

Pada tahap ini penyuluhan dilakukan dengan ceramah interaktif menggunakan media video dan powerpoint. Materi yang akan disampaikan berupa pemahaman dasar tentang pupuk dan hormon. Disela ceramah, dilakukan tanya jawab untuk mengkaji pemahaman petani terhadap materi yang diberikan.

\section{Praktik Pembuatan Zat Pengatur Tumbuh Organik}

Pembuatan ZPT organik diawali dengan proses ekstraksi kemudian dilanjutkan dengan proses fermentasi selama 2 minggu.

\section{Pengemasan dan pemasaran}

Kegiatan ini dilakukan dengan memberikan pengarahan terkait kewirausahaan, desain kemasan, serta mengemas produk dan aplikasi pada tanaman.

\section{Evaluasi}

Evaluasi tersebut dilakukan secara lisan dengan tanya jawab langsung serta dalam bentuk tertulis menggunakan kuisioner.

\section{HASIL DAN PEMBAHASAN}

Program pengabdian kepada Masyarakat yang dilaksanakan di Desa Sumberjambe, Kabupaten Jember tentang pembuatan Zat Pengatur Tumbuh (ZPT) organik cair pada Kelompok Tani Teladan dapat dinilai sudah berjalan dengan baik dan terjadwal. Program ini diawali dengan kegiatan adalah survei lokasi awal untuk mengetahui permasalahan dan potensi yang ada di desa tersebut.

Berdasarkan informasi dari petani, perwakilan apparat desa dan PPL bahwa petani lebih banyak menggunakan pupuk kimia daripada pupuk organik. Alasan para petani adalah karena memang terbiasa dan hasilnya juga memuaskan, langsung bisa terlihat pada tanaman. Terlebih lagi bahwa para petani khawatir akan terjadi penurunan produksi jika menggunakan pupuk organik. 
Selain itu, permasalahan lain adalah minimnya pengetahuan petani terhadap hormon/zat pengatur tumbuh tumbuhan. Para petani masih menganggap bahwa untuk pertumbuhan tanaman hanya menggunakan pupuk saja.

Setelah itu, tim pengabdian ini melakukan koordinasi dengan Ketua kelompok tani Teladan untuk langkah selanjutnya yaitu proses pelaksanaa pelatihan pembuatan zat pengatur tumbuh organik. Kegiatan pelatihan ini dilakukan menggunakan metode ceramah, diskusi dan praktek langsung pembuatan ZPT organik cair kemudian melakukan pengemasan dan kewirausahaan.

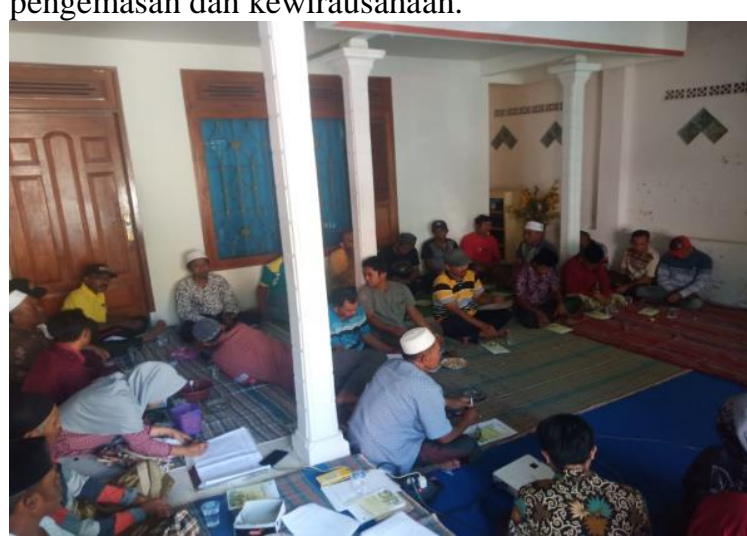

Gambar 1. Pemaparan materi kepada petani

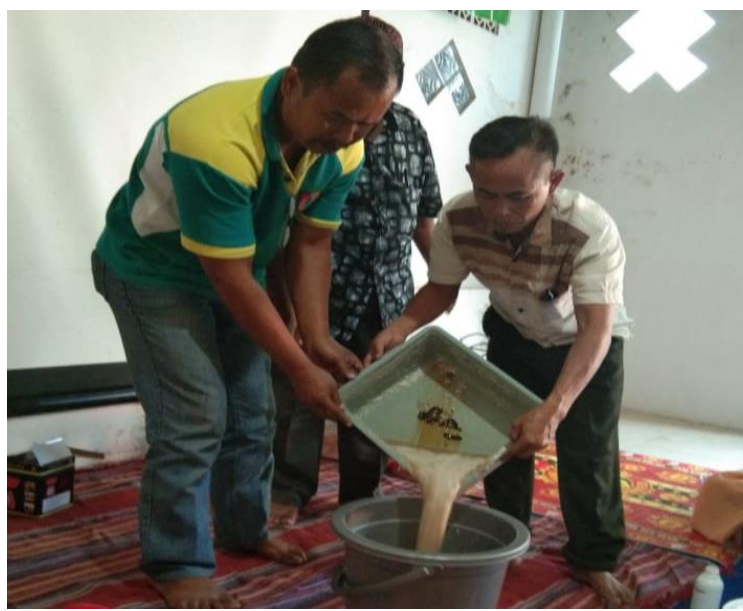

Gambar 2. Praktik langsung pembuatan ZPT organik

Dalam kegiatan ini, kemajuan hasil yang telah dicapai adalah terlaksananya kegiatan penyuluhan tentang zat pengatur tumbuh, praktik pembuatan ZPT organik serta terdapat larutan fermentasi zat pengatur tumbuh organik. Tahapan pembuatan ZPT organik ini masih dalam proses fermentasi dan harus menunggu selama kurang lebih 2 minggu agar ZPT organik dapat diaplikasikan pada tanaman. Selama proses fermentasi, larutan harus diaduk setiap 2 hari sekali.

Salah satu indikator capaian pelaksanaan pada tahapan awal berupa pelatihan pembuatan Zat pengatur tumbuh organik cair ini diukur dari respons kehadiran para peserta pelatihan yang dihadiri oleh 30 orang atau $100 \%$ undangan menghadiri acara pelatihan. Pada saat pelaksanaan kegiatan ekstraksi dan fermentasi bahan-bahan organik, terlihat bahwa peserta mengetahui urutan tata cara pembuatan ZPT organik dari hasil diskusi dan tanya jawab. Selain itu, penilaian keberhasilan secara kuantitatif dari kegiatan pengarahan dilakukan melalui pre-test dan post -test. Pre-test dilakukan sebelum penyampaian materi dan post-test setelah kegiatan praktek dilaksanakan. Hasil yang diperoleh pada tes awal rata-rata pemahaman tentang ZPT organik adalah 53, sedangkan rata-rata post-test setelah pelaksanaan adalah 79,2. Berdasarkan hasil pre test dan post test menunjukkan adanya peningkatan yang signifikan untuk pengetahuan peserta tentang zat pengatur tumbuh organik. Hasil ini juga dapat mengindikasikan bahwa kegiatan ini mampu meningkatkan pengetahuan peserta. Selain itu, data kuesioner menunjukkan bahwa $84 \%$ petani berminat membuat dan memasarkan produknya.

Pada praktiknya, peserta telah mampu mengekstraksi dan melakukan pencampuran bahan-bahan untuk proses fermentasi. Indikator keberhasilan tersebut terlihat dari bahan ZPT organik yang sudah terfermentasi dengan baik yang dicirikan dengan warna coklat dan bau asam menyerupai tape.

\section{KESIMPULAN}

Pelatihan ini mampu meningkatkan pengetahuan dan keterampilan petani untuk membuat ZPT organik cair dari bahan-bahan yang mudah didapat.

\section{UCAPAN TERIMA KASIH}

Kegiatan pengabdian kepada masyarakat ini dilaksanakan menggunakan dana Direktorat Riset dan Pengabdian Masyarakat (DRPM) Ristekdikti 2018

\section{DAFTAR PUSTAKA}

[1] Badan Pusat Statistik Kabupaten Jember, "Kecamatan Sumbejambe dalam Angka," 2017.

[2] S. N. Tan, J. W. H. Yong, and L. Ge, “Analyses of phytohormones in coconut (Cocos Nucifera L.) water using capillary electrophoresis-tandem mass spectrometry," Chromatography, vol. 1, no. 4, pp. 211-226, 2014.

[3] R. Bottini, F. Cassán, and P. Piccoli, "Gibberellin production by bacteria and its involvement in plant growth promotion and yield increase," Appl. Microbiol. Biotechnol., vol. 65, no. 5, pp. 497-503, 2004.

[4] T. Hartanto and Nugroho, "Peranan Berbagai Sumber Sitokinin Alami terhadap pertumbuhan in vitro Pisang Barangan (Musa Acuminata)," Universitas Sebelas Maret, 2016.

[5] Sudarso, Nelvia, and M. A. Khoiri, "Pemberian Zat Pengatur Tumbuh (Zpt) Alami Pada Bibit Kelapa Sawit (Elaeis Guineensis Jacq) Di Main-nursery," J. Online Mhs. Fak. Pertan. Univ. Riau, vol. 2, no. 2, pp. 1-7, 2015. 